\title{
Leuprolide acetate I-, 3- and 6-monthly depot formulations in androgen deprivation therapy for prostate cancer in nine European countries: evidence review and economic evaluation
}

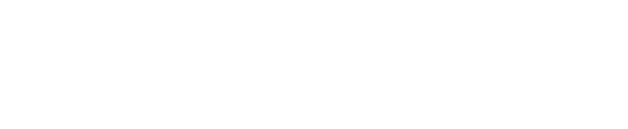

Jaro Wex'

Manpreet Sidhu²

Isaac Odeyemi ${ }^{2}$

Ahmed M Abou-Setta'

Peny Retsa ${ }^{2}$

Bertrand Tombal ${ }^{3}$

'PharmArchitecture Limited, London, UK; ${ }^{2}$ Astellas Pharma Europe Ltd, Chertsey, UK; ${ }^{3}$ Cliniques Universitaires Saint-Luc, Brussels, Belgium
Correspondence: Jaro Wex PharmArchitecture Limited, I45- I 57 St John Street, London, UK, ECIV 4PY

Tel +44 20 305 I I 424

Fax +4420305I 1435

Email jaro.wex@pharmarchitecture.com
Objective: Leuprolide is an established luteinizing hormone-releasing hormone (LHRH) agonist used as first-line treatment in advanced prostate cancer. As different formulations and dosing schedules are likely to have economic implications, we aimed to evaluate their efficacy, safety, and costs in nine European countries: Austria, Belgium, Czech Republic, Hungary, Italy, Latvia, Netherlands, Poland, and Portugal.

Methods: Database searches identified 13 clinical trials of leuprolide 1- (1 M), 3- (3 M) and 6-monthly (6 M). Only data on leuprolide with Atrigel were compared for all three formulations, which had the same efficacy, safety, and adherence. Cost-minimization analysis accounting for cost of Eligard $^{\circledR}$, specialist consultations, and diagnostics during up to 12 months follow-up was conducted. The perspective was that of public payers.

Results: No significant differences were observed in the percentages of intention-to-treat patients achieving testosterone levels $\leq 50 \mathrm{ng} / \mathrm{dL}$ following treatment with Eligard $^{\circledR} 1 \mathrm{M}(93.3 \%), 3 \mathrm{M}$ (98.3\%), and $6 \mathrm{M}(97.3 \%)(P>0.05)$, and adverse event profiles of the three formulations were comparable. Overall, $6 \mathrm{M}$ was the least expensive, with average total annual costs from $€ 788$ (Belgium) to $€ 1839$ (Portugal). The $3 \mathrm{M}$ option was between $2.5 \%$ (Hungary) and $37.6 \%$ (Belgium) more expensive than $6 \mathrm{M} ; 1 \mathrm{M}$ formulation was the most expensive, with costs $15.5 \%$ and $151.6 \%$ more expensive than $6 \mathrm{M}$ for those countries, respectively. The $3 \mathrm{M}$ option was $11.2 \%-45.3 \%$ less expensive than $1 \mathrm{M}$. Total costs were associated with frequency of visits for injection and monitoring. The $1 \mathrm{M}$ required twelve visits, $3 \mathrm{M} 4.4-4.8$ visits, and $6 \mathrm{M} 2.1-2.3$ visits. Up to $50 \%$ additional visits could be funded with the savings resulting from switching eligible patients from $1 \mathrm{M}$ and $3 \mathrm{M}$ to $6 \mathrm{M}$. Results were stable in univariate and probabilistic sensitivity analyses.

Conclusion: Eligard ${ }^{\circledR}$ formulations offer comparable efficacy and safety, but different dosing schedules require different number of visits. The $6 \mathrm{M}$ formulation offers the greatest cost savings and should be considered the treatment of choice in eligible patients in Europe.

Keywords: prostate, cancer, androgen, leuprolide, Eligard, cost-effectiveness

\section{Introduction}

Prostate cancer, the most frequently diagnosed cancer in adult males in most European countries, was estimated to constitute $29.8 \%$ of all new cases of cancer in males in 2012, with 417,000 new cases identified each year, a standardized incidence of 96.0 per 100,000 men, ${ }^{1,2}$ and the 5-year prevalence of the disease totaling $1,525,795$ cases. $^{3}$ Prostate cancer still remains the third leading cause of cancer death in men $(9.1 \%)$, after lung and colorectal cancer. ${ }^{4}$ Due to earlier detection and availability of 
innovative treatments, the incidence of metastatic prostate cancer has been shown to be less than $2 \%$ of patients. ${ }^{5,6}$ Even so, treatment failure is increasing and even in patients with an initial response to treatment, $40 \%$ of patients have been shown to experience recurrence. ${ }^{7,8}$

Currently treatment with luteinizing hormone-releasing hormone (LHRH) agonists, which has been available for over 15 years, is the predominant form of androgen deprivation therapy (ADT) and has become the standard of care for metastatic prostate cancer. ${ }^{9,10}$ Historically, ADT was accomplished by bilateral surgical orchiectomy. This method is considered to be the gold standard to which all other methods are compared for decreasing testosterone levels. ${ }^{9}$ However, it is irreversible and may carry an unintended emotional and psychological burden for patients. ${ }^{11}$ Importantly, while affecting patients' quality of life, orchiectomy does not offer any survival advantage when compared to LHRH agonists. ${ }^{12}$ Indeed, the quality-of-life-adjusted survival disadvantage of orchiectomy was reported in an economic study in Japan. ${ }^{13}$ ADT has evolved as a standard option for treatment of patients with advanced prostate cancer, especially as an adjuvant for patients primarily treated by radiation therapy, ${ }^{14}$ as well as those with locally advanced disease, ${ }^{15}$ either as a stand-alone or as adjuvant and neoadjuvant treatment. Currently, ADT is also being used in earlier stages of prostate cancer and in cases of biochemical failure after curative treatment. ${ }^{16}$ Due to their reversibility upon treatment cessation, LHRH agonists are being increasingly used to treat patients with biochemical failure, regardless of spread, for shorter periods, and as neoadjuvant or adjuvant therapy to radiotherapy or prostatectomy. ${ }^{17}$ Moreover, there is evidence from randomized controlled trials (1b) that immediate initiation of hormone suppression decreases the risk of progression and improves overall survival. ${ }^{9,18}$

The European Association of Urology recommends ADT with LHRH agonists as the first-line of treatment for both symptomatic and asymptomatic patients in advanced disease, as well as in locally advanced symptomatic patients, alongside radiotherapy, and in cases when radical treatment is not recommended or when such treatment is not possible..$^{9,19}$ For localized disease, no randomized study has compared the effectiveness of the three treatment modalities - ie, radical prostatectomy, radiotherapy, and hormonal treatment - and existing evidence does not support superiority of one modality over the others. ${ }^{20}$ Therefore, patients' preference for treatment modality and clinical consideration of patients' age and predictive/biological characteristics are very important in determining the treatment of choice in patients with localized prostate cancer. ${ }^{21,22}$
To address clinical need and patient preferences, innovative depot formulations of LHRH were developed, resulting in a marked decrease in the amount of LHRH required when compared to daily injection formulations. ${ }^{23}$ Recently, newer, longer-acting depot formulations of leuprolide acetate with a sustained effect of up to 6 months have been made available in Europe. Leuprolide is also available with a proprietary polymeric delivery system as Eligard ${ }^{\circledR}$ (leuprolide with Atrigel ${ }^{\circledR}$, a registered trademark of Sanofi S.A./Tolmar Therapeutics Inc [Fort Collins, CO, USA]). Atrigel $^{\circledR}$ (QLT USA, Inc, Fort Collins, CO, USA), consists of a biodegradable polymer dissolved in a biocompatible liquid solvent to form a liquid gel. After mixing with leuprolide prior to injection, the formulation is injected subcutaneously and forms a solid single sphere implant in situ. ${ }^{24,25}$ Over time this leuprolide depot biodegrades to release the drug, allowing for continuous administration of leuprolide acetate. The earlier depot formulations of leuprolide use lyophilized microsphere (10-30 mm) drug delivery systems. ${ }^{26}$ Leuprolide microspheres contain the active compound in biodegradable, highly lipophilic synthetic polymer microspheres. ${ }^{27,28}$ However, the single relatively large sphere formed by Atrigel presents a smaller surface area protecting the leuprolide acetate from degradation on the surface.

The advantage of Eligard ${ }^{\circledR}$ over conventional shorteracting depot products has made it a potential standard of care for patients eligible for ADT. In Europe, Eligard ${ }^{\circledR}$, which contains double the amount of leuprolide found in other leuprolide-based products, is currently commercially available in three depot formulations of $7.5 \mathrm{mg}, 22.5 \mathrm{mg}$, and $45 \mathrm{mg}$ doses for 1-monthly (1 M), 3-monthly (3 M), and 6-monthly (6 M) administration intervals, respectively. In a survey, 77\% of urologists stated that they preferred the use of $6 \mathrm{M}$ depot rather than shorter time formulations. ${ }^{29}$ Patient preference also plays a role for choosing formulations with different dosing schedules. In a French study of locally advanced and metastatic prostate cancer, all patients treated with both $3 \mathrm{M}$ and $6 \mathrm{M}$ Eligard $^{\circledR}$ considered the $6 \mathrm{M}$ formulation an improvement over $3 \mathrm{M} .{ }^{30}$ Even though the patient reported advantage of the $3 \mathrm{M} \mathrm{LHRH}$ agonist was the high satisfying quality of medical follow-up, the $6 \mathrm{M}$ formulation had the advantages of flexibility and the freedom from worrying about their cancer for up to 6 months. Among the advantages reported for the $6 \mathrm{M}$ depot were reduced anxiety, decreased emotional burden, improved flexibility with scheduling, less frequent injections, improved comfort, fewer doctor visits, decreased site reactions, decreased cost, fewer missed visits and, in theory, decreased risk of breakthrough. ${ }^{31}$ In Germany 
the long dosing interval of $6 \mathrm{M}$ leuprolide was the main reason given by urologists for making the prescribing decision with regard to the hormone deprivation therapy. ${ }^{32}$ According to clinicians who participated in the study, patients with stable disease, patients who need to travel, or those who have difficulty reaching the practice, may benefit from less frequent injections.

The availability of three different formulations of Eligard ${ }^{\circledR}$ allows for greater flexibility in meeting clinical needs and patients' preferences. It also invites an inquiry into their relative efficacy and cost-effectiveness to aid clinical decision making, as well as to inform the allocation of resources at the health system level. Dosing frequency was found to have an impact on cost effectiveness, where the cost-neutrality of goserelin versus leuprolide was achieved when the leuprolide $3 \mathrm{M}$ formulation was used. ${ }^{33}$ Less frequent administration of leuprolide, as in the $6 \mathrm{M}$ formulation, would be expected to be more cost effective. The availability of the new depot formulations of leuprolide, as well as the clinical use of other pharmaceuticals (also in different doses), highlights the importance of the assessment of both relative effectiveness and relative costs of leuprolide treatment options. In the USA, the trend of increased prescription of LHRH agonists by urologists was reversed by recent regulations affecting the reimbursement of this method of treatment, ${ }^{34}$ indicating that the choice of medical or surgical castration in patients with prostate cancer seems to be directly related to reimbursement schemes. Therefore, it is vital that the relative value for money of different treatment modalities is established as a basis for recommendations.

In European countries, there is no single payment plan available and each health care system functioning as a separate entity, often with markedly differing regulations. In addition, patients are treated in different settings (inpatient, secondary/tertiary care outpatient, primary care), which is inherently associated with different costs. Additionally, costs of medical services and drugs can vary considerably. A recent cost-effectiveness analysis demonstrated that despite higher price per injection, the use of the $45 \mathrm{mg} 6 \mathrm{M}$ formulation of Eligard ${ }^{\circledR}$ was a cost-saver for the German health care system. ${ }^{35}$ The analysis showed that the $6 \mathrm{M}$ formulation was the lowest cost treatment option when considering the cost of products used and the cost of hospital visits, the two main cost drivers. As ADT carries considerable health care budget implications, we sought to establish the relative effectiveness and costs of treatment with these three formulations in nine European countries: Austria, Belgium, Czech Republic, Hungary, Italy, Latvia, Netherlands, Poland, and Portugal.
The countries were chosen to reflect various geographies (East and West), size (smaller and larger), financing systems (health care funds and tax funded), and income per capita, to increase generalizability of results.

\section{Methods Clinical evidence}

Major databases (MEDLINE, EMBASE, and Cochrane) were systematically searched in September 2012 to identify studies of $1 \mathrm{M}, 3 \mathrm{M}$ and $6 \mathrm{M}$ depot formulations of leuprolide acetate in the treatment of prostate cancer. All dosages were considered (ie, $3.75 \mathrm{mg}, 7.5 \mathrm{mg}, 11.25 \mathrm{mg}, 22.5 \mathrm{mg}$, and $45 \mathrm{mg}$ doses). Search terms [(prostate OR prostatic) AND (cancer OR carcinoma) AND (leuprolide OR leuprorelin OR Eligard)] with no filters applied yielded 754 results, abstracts of which were screened for relevance by two of the authors (JW and AA). Individual case reports and studies not reporting levels of testosterone both at day 28/month 1 , and at the end of treatment using both a $20 \mathrm{ng}$ and $50 \mathrm{ng} / \mathrm{dL}$ threshold were excluded. Full texts of 49 articles were obtained and reviewed by at least one of the authors. As a result of the review, twelve studies reporting 13 comparisons were identified: one randomized trial comparing leuprolide to another LHRH agonist; ${ }^{36}$ nine prospective case series; ${ }^{16,24,37-43}$ and three retrospective case series (Table 1). ${ }^{44,45}$ A review of references yielded no additional reports. The $1 \mathrm{M}$ formulation was used in five studies, $3 \mathrm{M}$ in six studies, and $6 \mathrm{M}$ in two studies. Of all the identified studies, only four reported testosterone levels both at 28 days and at the end of treatment and for both 20 and $50 \mathrm{ng} / \mathrm{dL}$. With incomplete reporting in the remaining studies, a comparison of efficacy could not be conducted. In addition, when castration rates at 28 days were compared within dosing schedules but between different leuprolide products, Eligard ${ }^{\circledR}$ had significantly higher success rate than one other leuprolide product, Lorelin (96.5\% versus $83.7 \%$, Chi-square, $P<0.0001) .{ }^{16}$ This finding, although based on studies with different designs and different patient populations, suggested that only identical products should be included in the comparison. Therefore, three Eligard ${ }^{\circledR}$ studies, all prospective, using the leuprolide gel formulation and reporting testosterone at both $50 \mathrm{ng} / \mathrm{dL}$ and $20 \mathrm{ng} / \mathrm{dL}$, were included in the analysis. The dosage in Eligard ${ }^{\circledR}$ formulations was $7.5 \mathrm{mg}$ in $1 \mathrm{M}, 22.5 \mathrm{mg}$ in $3 \mathrm{M}$, and $45 \mathrm{mg}$ in $6 \mathrm{M}$. In the identified studies, neither serious adverse events, nor deaths related to treatment, were reported. Frequency of treatmentrelated severe adverse events was small $(0 \%-2 \%)$ in all studies and comparable between the included and excluded studies $(P>0.1)$, where data had been reported. In addition, 
Table I Identified studies reporting use of leuprolide in the treatment of advanced prostate cancer

\begin{tabular}{|c|c|c|c|c|c|c|}
\hline Study & $\begin{array}{l}\text { Formulation, dose, } \\
\text { max study duration }\end{array}$ & Cases & $\begin{array}{l}\text { Mean [median] } \\
\text { T level }\end{array}$ & $\begin{array}{l}\text { \% suppression } \\
\text { [per evaluable pt] } \\
\text { (at study end) at } \\
50 \mathrm{ng} / \mathrm{mL}\end{array}$ & $\begin{array}{l}\text { \% suppression } \\
\text { [per evaluable pt] } \\
\text { (at study end) at } \\
20 \mathrm{ng} / \mathrm{mL}\end{array}$ & $\begin{array}{l}\text { Study type and } \\
\text { PCa stage }\end{array}$ \\
\hline Perez-Marreno ${ }^{37, *}$ & I M Eligard, 7.5 mg, 6 M & 120 & 6.3 & $\begin{array}{l}93.3[94 . \mathrm{I}] \\
(99.3 \text { at } 6 \mathrm{M})\end{array}$ & $\begin{array}{l}95.8[97.5] \text { at } 42 \mathrm{D} \\
(95.8 \text { at } 6 \mathrm{M})\end{array}$ & $\begin{array}{l}\text { Prospective; } \mathrm{PCa} \\
\mathrm{Cl} \text { or greater, } \\
\mathrm{T} 3 \text { or greater }\end{array}$ \\
\hline Heyns $^{36}$ & I M Eligard, 7.5 mg, 9 M & 140 & NR & 99.3 & $(97.3$ at $2-9 \mathrm{M})$ & $\begin{array}{l}\text { Prospective } \\
\text { cohort (RCT arm); } \\
\text { advanced PCa }\end{array}$ \\
\hline Fujii ${ }^{44}$ & $\begin{array}{l}\text { I M Enantone, } 3.75 \mathrm{mg} \text {, } \\
\text { up to } 10 \mathrm{Y}\end{array}$ & 40 & 11.0 & 95.0 & & $\begin{array}{l}\text { Retrospective; } \\
\text { metastatic and non- } \\
\text { metastatic }\end{array}$ \\
\hline Marberger $^{38}$ & $\begin{array}{l}\text { I M Lutrate, } 3.75 \mathrm{mg} \text {, } \\
24 \mathrm{~W}\end{array}$ & 160 & 4.12 & $\begin{array}{l}95.0[96.8] \\
(95.0 \text { at } 24 \mathrm{~W})\end{array}$ & $\begin{array}{l}71.3[73.1] \\
(88.1 \text { at } 24 \mathrm{~W})\end{array}$ & $\begin{array}{l}\text { Prospective; all } \\
\text { stages }\end{array}$ \\
\hline You $^{16}$ & $\begin{array}{l}\text { I M Lorelin, } 3.75 \text { mg, } \\
\text { I2 W }\end{array}$ & 104 & NR & $\begin{array}{l}83.7[93.8] \\
(82.7 \text { at } 3 \mathrm{M})\end{array}$ & & $\begin{array}{l}\text { Prospective; all } \\
\text { stages }\end{array}$ \\
\hline $\mathrm{Chu}^{24, *}$ & $\begin{array}{l}3 \mathrm{M} \text { Eligard, } 22.5 \mathrm{mg}, \\
6 \mathrm{M}\end{array}$ & 117 & 10.1 & $\begin{array}{l}98.3[99.1] \\
(94.9 \text { at } 6 \mathrm{M})\end{array}$ & $\begin{array}{l}83.8[84.5] \\
(88.9 \text { at } 6 \mathrm{M})\end{array}$ & $\begin{array}{l}\text { Prospective; } \\
\mathrm{PCa}>\mathrm{A} 2>\mathrm{TI}\end{array}$ \\
\hline Oefelein $^{39}$ & $\begin{array}{l}3 \text { M Eligard, } 22.5 \text { mg, } \\
18 \text { M (single dose) }\end{array}$ & 13 & {$[10]$} & & 92 & $\begin{array}{l}\text { Prospective; } \\
\text { localized PCa }\end{array}$ \\
\hline Oefelein ${ }^{40}$ & $\begin{array}{l}3 \text { M Eligard, } 22.5 \mathrm{mg}, \\
\text { I2+ M, I-2 doses }\end{array}$ & 32 & [20] & & 97 & $\begin{array}{l}\text { Prospective; } \mathrm{T} 3 \mathrm{~N} \pm \\
\mathrm{M} \pm \text { or greater }\end{array}$ \\
\hline $\begin{array}{l}\text { Oefelein and } \\
\text { Cornum }{ }^{41}\end{array}$ & $\begin{array}{l}3 \text { M Eligard, } 22.5 \text { mg, } \\
15 \text { M (single dose) }\end{array}$ & 38 & NR & 94.7 & 86.8 & $\begin{array}{l}\text { Prospective; } \\
\text { advanced } \mathrm{PCa}\end{array}$ \\
\hline$Y_{r i}{ }^{45}$ & $\begin{array}{l}3 \mathrm{M} \text { Enantone, II.25 mg, } \\
12 \mathrm{~W}\end{array}$ & 40 & 17.3 & & & $\begin{array}{l}\text { Retrospective } \\
\text { series; locally } \\
\text { advanced }\end{array}$ \\
\hline Fujii ${ }^{44}$ & $\begin{array}{l}3 \mathrm{M} \text { Enantone, } 11.25 \mathrm{mg} \text {, } \\
\text { up to } 10 \mathrm{Y}\end{array}$ & 68 & 12.0 & 98.5 & & $\begin{array}{l}\text { Retrospective } \\
\text { series; metastatic } \\
\text { and non-metastatic }\end{array}$ \\
\hline Crawford ${ }^{42, *}$ & $\begin{array}{l}6 \mathrm{M} \text { Eligard, } 45 \mathrm{mg} \text {, } \\
12 \mathrm{M}\end{array}$ & 103 & 12.3 & $\begin{array}{l}97.3[99.1] \\
(91.9 \text { at } 12 \mathrm{M})\end{array}$ & $\begin{array}{l}82.9[84.4] \\
(82.0 \text { at I2 M) }\end{array}$ & $\begin{array}{l}\text { Prospective; } \\
\text { PCa }>\text { TI, A2-A4 }\end{array}$ \\
\hline Spitz ${ }^{43}$ & $\begin{array}{l}6 \mathrm{M} \text { Lupron, } 45 \mathrm{mg} \text {, } \\
48 \mathrm{~W}\end{array}$ & 151 & 15 & $\begin{array}{l}93.4[93.6] \\
(93.4 \text { at } 48 \mathrm{~W})\end{array}$ & & $\begin{array}{l}\text { Prospective; stage } \\
2-4 \text {, also PSA failure }\end{array}$ \\
\hline
\end{tabular}

Notes: *Included in the analysis. Registered trademarks: Eligard ${ }^{\circledR}$, Sanofi S.A./Tolmar Therapeutics Inc (Fort Collins, CO, USA); Enantone ${ }^{\circledR}$, Takeda (Osaka, Japan); Lutrate ${ }^{\circledR}$, GP Pharm S.A. (Barcelona, Spain); Lorelin ${ }^{\circledR}$, Dongkook (Seoul, South Korea); Lupron ${ }^{\circledR}$, Abbott Laboratories (North Chicago, IL, USA).

Abbreviations: PCa, prostate cancer; D, days; W, weeks; M, months; Y, years; NR, not reported; PSA, prostate-specific antigen.

there were no significant differences between the $1 \mathrm{M}, 3 \mathrm{M}$, and $6 \mathrm{M}$ formulations regarding their safety profiles and dropout rates. The most common reported side effect, applicable to LHRH agonists in general, was hot flushes.

\section{Economic model}

As no differences in efficacy and safety of the three formulations were found, we conducted a cost-minimization analysis combining resource utilization and unit costs associated with the compared treatment options. Nine European countries with different health care systems were chosen in an attempt to increase the generalizability of the results. Specifically, the countries differed in the relative role of primary care versus secondary care specialists in prescribing and administering hormonal ADT. Countries also differed considerably with regard to unit costs of resources used. A health economic model was implemented in MS Excel (Microsoft Corporation, Redmond, WA, USA), allowing for the attribution of costs to all treatment events during a 12-month period. As drop-out rates were not significantly different and there was no evidence on mortality, only differential costs were considered (ie, those of different Eligard ${ }^{\circledR}$ formulations, specialist consultations, and diagnostic tests). In the model, patients were initiated on leuprolide in one of three different settings: hospital (urology outpatient); community (urology outpatient); or primary care (general practitioner). A small number of patients were given leuprolide injections as inpatients, but they were not considered in the analysis; due to relatively high cost of hospitalization, this was deemed a conservative assumption. Specifically, patients receiving leuprolide while hospitalized during neoadjuvant or adjuvant hormonal therapy were not considered. Modeled patient 
cohorts continued on treatment for a time of simulation of up to 12 months, with a trials-based percentage of patients dropping out; however, an average drop-out rate of $4.93 \%$ was assumed, as the slight differences were not statistically significant. Some patients treated with $3 \mathrm{M}$ had diagnostic/ monitoring visits in addition to visits during which injections were administered; additionally, some patients on the $6 \mathrm{M}$ formulation were assumed to come for diagnostic/monitoring visits more frequently to comply with treatment guidelines based on individual response. The required expert opinion on additional visits was obtained from practicing urologists in each country. In cases where the costs of diagnostics (prostatespecific antigen, ultrasound) were not covered by the standard outpatient tariff, they were attributed separately. Costs were based on the latest available data from 2010 obtained in the local currency unit and converted to euro at the interbank rate, where applicable. Costs were updated applying 3\% inflation rate. No discounting was used in modeling due to the short time horizon.

Univariate (one-way) sensitivity analyses were conducted by individually varying all the parameters in the model. Probabilistic sensitivity analysis, based on a cohort of 10,000 individually simulated patients (Monte Carlo simulation), addressed joint uncertainty in all input variables; parameters were varied within $95 \%$ uncertainty intervals or by $\pm 25 \%$ of the mean estimate, and no correlation between parameters was assumed. The main analysis was conducted from the perspective of the public payer. In addition, we ran the model with the alternative scenario including nonmedical (transportation) costs incurred by patients, as well as societal costs based on lost productivity; these were negligible considering patients' retirement status. Unit costs used in the analysis are shown in Table 2.

\section{Results}

Based on the three trials included in the economic analysis, no significant differences were observed in the percentages of intent-to-treat patients achieving testosterone levels $\leq 50 \mathrm{ng} / \mathrm{dL}$ following treatment with Eligard ${ }^{\circledR} 1 \mathrm{M}$ (93.3\%), $3 \mathrm{M}(98.3 \%)$, and $6 \mathrm{M}(97.3 \%)(P<0.05)$. The values per patient receiving treatment and at study end for the $50 \mathrm{ng} / \mathrm{dL}$ and $20 \mathrm{ng} / \mathrm{dL}$ cut-off points are shown in Table 1.

Safety profiles of the three formulations were comparable. No deaths or serious adverse effects related to treatment were reported, and mild to moderate hot flashes were the most common treatment-related adverse effects in each study; mild and moderate hot flashes occurred in $44 \%$ and $12 \%$ of Eligard $^{\circledR} 1 \mathrm{M}$ recipients, $49 \%$ and $10 \%$ of $3 \mathrm{M}$ recipients, and $33 \%$ and $24 \%$ of $6 \mathrm{M}$ recipients, respectively.

Our economic analyses revealed that in all nine European countries leuprolide $6 \mathrm{M}$ was the least expensive treatment option, with the average total annual costs per patient varying from $€ 788$ in Belgium to $€ 1839$ in Portugal.

Table 2 Cost, resource utilization, and market share data from nine European countries used to populate the economic model

\begin{tabular}{|c|c|c|c|c|c|c|c|c|c|}
\hline & Austria & Belgium & $\begin{array}{l}\text { Czech } \\
\text { Republic }\end{array}$ & Hungary & Italy & Latvia & $\begin{array}{l}\text { The } \\
\text { Netherlands }\end{array}$ & Poland & Portugal \\
\hline \multicolumn{10}{|l|}{ Costs (€) } \\
\hline Eligard $^{\circledR}$ I M (7.5 mg) & 106.80 & 95.70 & 121.60 & 100.39 & 149.77 & 111.66 & $106.80 *$ & 81.78 & 148.20 \\
\hline Eligard ${ }^{\circledR} 3$ M (22.5 mg) & 320.40 & 194.52 & 314.95 & 280.55 & 387.49 & 319.03 & 320.40 & 240.57 & 399.41 \\
\hline Eligard ${ }^{\circledR} 6$ M (45 mg) & 619.22 & 320.06 & $629.93 * *$ & 558.II & 774.98 & 466.87 & 619.22 & 481.14 & 779.66 \\
\hline Urologist consultation $\S$ & 29.42 & 28.56 & 4.23 & 2.42 & 20.70 & 38.96 & 86.00 & 8.65 & 35.43 \\
\hline PSA test & 11.10 & 10.78 & 14.46 & 4.75 & 19.10 & 7.14 & 27.65 & 7.21 & 8.14 \\
\hline Ultrasound scan & 27.66 & 37.37 & 12.10 & 1.80 & 43.40 & 12.99 & 85.00 & 7.21 & 43.16 \\
\hline Adverse events ${ }^{\#}$ & 21.80 & 18.24 & 4.23 & 1.79 & 20.70 & 16.88 & 86.00 & 3.85 & 35.43 \\
\hline $\begin{array}{l}\text { Nonmedical cost per } \\
\text { visit }^{\ddagger}\end{array}$ & 5.70 & 4.40 & 3.57 & 5.22 & 4.00 & 10.39 & 7.00 & 2.16 & 4.20 \\
\hline Indirect cost per visit"l & 23.81 & 33.70 & 6.80 & 6.25 & 28.57 & 6.18 & 33.91 & 7.93 & 11.55 \\
\hline \multicolumn{10}{|c|}{ Resource utilization (\%) - diagnostic visits } \\
\hline Monthly & 0.24 & 0.24 & 0.90 & 0.88 & 0.90 & 0.90 & 0.24 & 0.90 & 0.90 \\
\hline 3-monthly & 4.75 & 4.75 & 9.00 & 8.77 & 9.00 & 9.00 & 4.75 & 9.00 & 9.00 \\
\hline \multicolumn{10}{|c|}{ Estimated market share (\%) } \\
\hline Eligard ${ }^{\circledR}$ I M & 20.0 & 30.0 & 10.4 & 32.0 & 10.0 & 15.0 & 0 & 2.2 & 8.0 \\
\hline Eligard $^{\circledR} 3 \mathrm{M}$ & 60.0 & 70.0 & 90.6 & 68.0 & 87.0 & 80.0 & 20.2 & 65.8 & 90.0 \\
\hline
\end{tabular}

Notes: *I M formulation was not marketed and its unit cost was assumed to be one-third of the $3 \mathrm{M}$ formulation; **monthly cost assumed to be equivalent to that of $3 \mathrm{M}$ and was varied in the sensitivity analysis; ${ }^{\circledR}$ doctor, nurse, and injection costs; \#GP/urologist consultation; "public transport; "productivity loss based on minimum wage and accounting for retirement status. Registered trademarks of Eligard ${ }^{\circledR}$, Sanofi S.A./Tolmar Therapeutics Inc (Fort Collins, CO, USA).

Abbreviations: I M, I-monthly; 3 M, 3-monthly; 6 M, 6-monthly; PSA, prostate-specific antigen; GP, general practitioner. 
The $3 \mathrm{M}$ option was between $2.5 \%$ in Hungary and $43 \%$ in Latvia more expensive than the $6 \mathrm{M}$ formulation, while the $1 \mathrm{M}$ formulation was the most expensive and between $15.5 \%$ and $151.6 \%$ more expensive than $6 \mathrm{M}$, for those countries respectively. The $3 \mathrm{M}$ option was between $11.2 \%$ and $45.3 \%$ less expensive than $1 \mathrm{M}$. Annual treatment costs in all nine countries are shown in Figure 1. The relative cost savings are visualized in Figure 2. When the societal perspective was adopted, with non-medical and indirect costs added, the cost advantages from using leuprolide $6 \mathrm{M}$ were slightly greater. Detailed cost results are shown in Table 3.

The cost of the drug was also the highest in the $1 \mathrm{M}$ option and varied from $€ 981-€ 1797$, while $3 \mathrm{M}$ cost $€ 778-€ 1598$, and $6 \mathrm{M} € 640-€ 1559$ (Figure 3 and Table 3 ). The total costs were associated primarily with the frequency of visits for injection and monitoring. While leuprolide $1 \mathrm{M}$ required twelve visits per annum, $3 \mathrm{M}$ was associated with an average of 4.4-4.8 visits, and $6 \mathrm{M}$ with 2.1-2.3 visits, accounting for additional monitoring visits. The upper limit on percentage of additional visits which could be funded with the savings resulting from switching eligible patients from $1 \mathrm{M}$ and $3 \mathrm{M}$ to $6 \mathrm{M}$ was estimated in different countries from $3.2 \%-50.0 \%$ (Figure 4).

Results were stable in all one-way sensitivity analyses, with only the costs of medical consultations (visits) associated with drug injections and monthly costs of leuprolide having significant impact on results. Sensitivity to cost of visits is evident in the variation in results across the nine analyzed countries. Figure 5 shows the total annual treatment cost with leuprolide $6 \mathrm{M}$ as a function of multiples of a monthly cost of leuprolide $1 \mathrm{M}$ (dashed grey line) and $3 \mathrm{M}$ (dashed black line) in Belgium. The solid lines represent annual treatment costs with $1 \mathrm{M}$ (grey) and $3 \mathrm{M}$ (black). The monthly drug cost of leuprolide $6 \mathrm{M}$ could be increased by $187 \%$ (nearly trebled), at which point total annual treatment costs of $1 \mathrm{M}$ and $6 \mathrm{M}$ would be the same. Equivalence of $3 \mathrm{M}$ and $6 \mathrm{M}$ would be achieved at the monthly cost of leuprolide $6 \mathrm{M} \mathrm{46 \%}$ greater than that of $3 \mathrm{M}$. The respective equivalence points for other countries were as follows: Austria 3.08 and 1.51; Czech Republic 1.16 and 1.06; Hungary 1.16, 1.03; Italy 1.68 and 1.13; Latvia 1.84 and 1.47; The Netherlands 2.62 and 1.40; Poland 1.25, 1.06; and Portugal 1.90, 1.22. In the probabilistic sensitivity analyses, the $95 \%$ uncertainty intervals ( $95 \%$ of the simulated cohort) for total costs and for the percentage of additional visits did not overlap (Table 3 ), affirming the robustness of mean estimates.

\section{Discussion}

Based on evidence from the included clinical trials, ${ }^{24,37,42}$ we established that there is no difference in efficacy of testosterone suppression and safety between the three longterm formulations of leuprolide. The cost-minimization analyses showed that Eligard ${ }^{\circledR} 1 \mathrm{M}$ is the most expensive treatment option in all nine European countries, while Eligard $^{\circledR} 6 \mathrm{M}$ offers cost savings compared to the other two. The savings resulted primarily from reduced resource

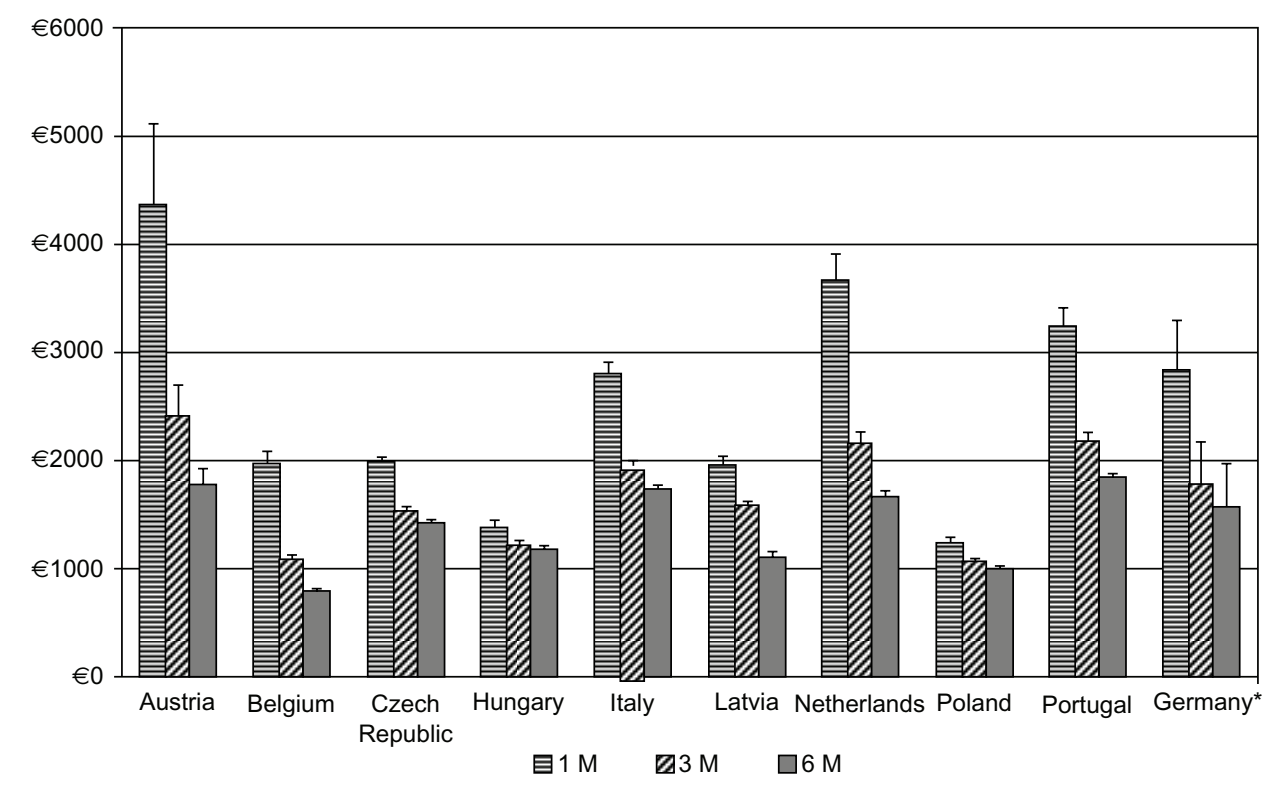

Figure I Annual treatment cost with Eligard ${ }^{\circledR}$ I M, 3 M, and 6 M in the nine analyzed countries and Germany.

Notes: *Values for Germany were extracted from Odeyemi et al ${ }^{35}$ (2007 analysis) and inflated to $201 \mathrm{I}$. Error bars correspond to $95 \%$ uncertainty intervals. Registered trademarks of Eligard ${ }^{\circledR}$, Sanofi S.A./Tolmar Therapeutics Inc (Fort Collins, CO, USA).

Abbreviations: I M, I-monthly; 3 M, 3-monthly; 6 M, 6-monthly. 


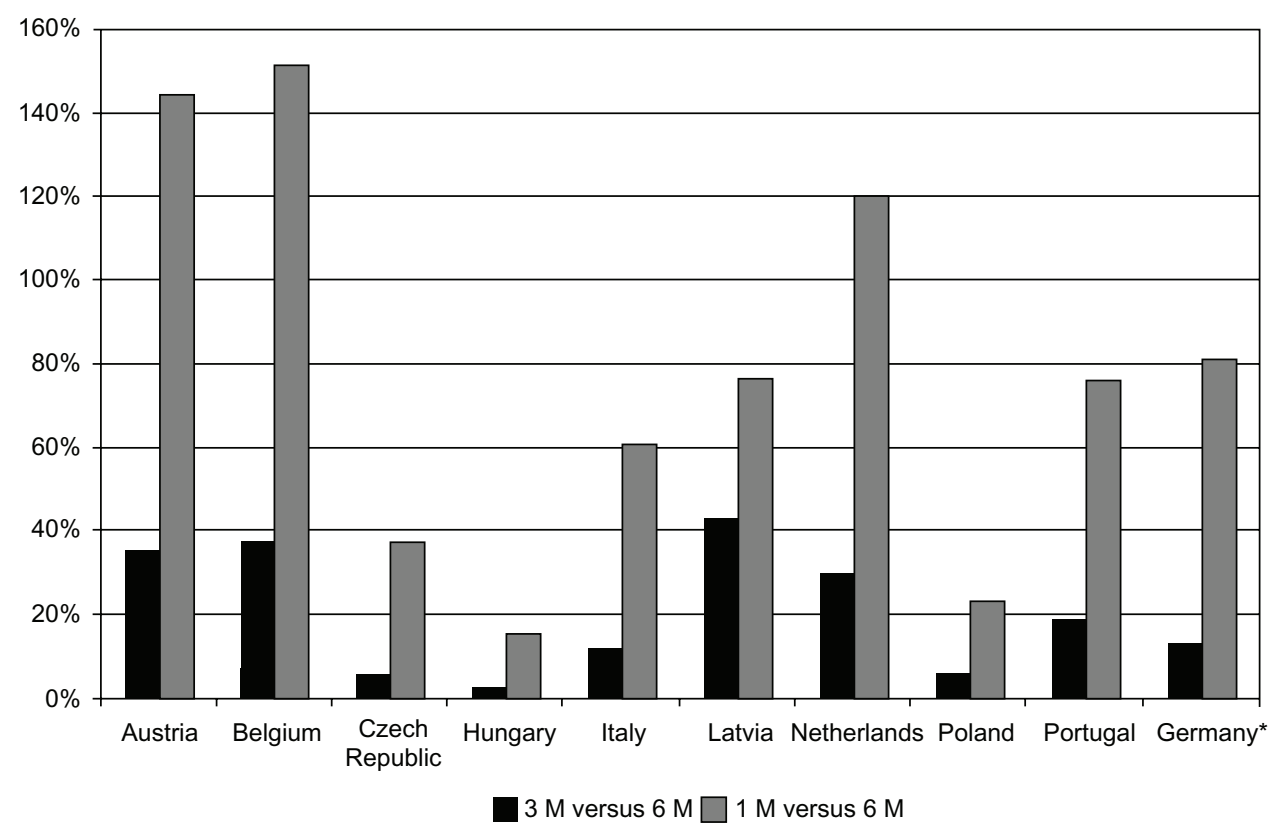

Figure 2 Percentage cost increase with Eligard ${ }^{\circledR}$ I M and Eligard ${ }^{\circledR} 3 \mathrm{M}$ compared to Eligard ${ }^{\circledR} 6 \mathrm{M}$.

Note: *Values for Germany were extracted from Odeyemi et $\mathrm{al}^{35}$ (2007 analysis) and inflated to 20I I. Registered trademarks of Eligard ${ }^{\circledR}$, Sanofi S.A./Tolmar Therapeutics Inc (Fort Collins, CO, USA).

Abbreviations: I M, I-monthly; 3 M, 3-monthly; 6 M, 6-monthly.

utilization (ie, fewer visits required for less frequent injections). The savings were greatest in countries with the highest costs associated with visits (Belgium and Portugal), but even in the country with the lowest reimbursement level, Poland, marginal cost savings could be achieved. The significance of our findings is highlighted by the high prevalence of prostate cancer and in the context of financial constraints faced by all health care systems; when health care spending cannot be increased, financing of cost saving interventions can make other treatments available.

Our results are consistent across the nine European countries analyzed, although potential savings from switching to leuprolide $6 \mathrm{M}$ were relatively small in Central/ Eastern European countries (Czech Republic, Hungary, and Poland). The size of savings was directly related to costs of treatment visits. Importantly, we have selected countries with different reimbursement systems and with different relative roles of general practice and urological care in the treatment process. Specifically, in Belgium, a considerable number of patients are treated in primary care, while in Portugal patients are managed almost exclusively by urologists. Ultimately, however, it is not the care setting, but rather the cost of visit, diagnostics, and drug administration that determine the economic aspects of different treatment options.

A similarly designed economic study evaluated different formulations of Eligard ${ }^{\circledR}$ in Germany. ${ }^{35}$ The mean annual treatment costs using the $1 \mathrm{M}, 3 \mathrm{M}$, and $6 \mathrm{M}$ formulations were
$€ 2839$ (standard deviation [SD] €233), €1777 (SD €195), and $€ 1567$ (SD $€ 205$ ), respectively. Thus, the mean annual costs of using $1 \mathrm{M}$ and $3 \mathrm{M}$ were $81 \%$ and $13 \%$ higher, respectively, than the cost of treatment with the $6 \mathrm{M}$ formulation. These figures broadly correspond to the savings on Eligard ${ }^{\circledR}$ determined in our analysis for Portugal, were smaller than in Belgium, and greater than in the Czech Republic, Hungary, and Poland. Both in the German study, ${ }^{35}$ and in our study, the economic advantage of the $6 \mathrm{M}$ formulation resulted from the reduction in the frequency of injections. Fewer clinic visits also means less anxiety and disruption in patients' lives. In addition, fewer injections could have quality of life implications due to less frequent occurrence of adverse events; site reaction at the injection site is one of the most commonly reported treatment-related adverse events. Finally, the $6 \mathrm{M}$ injections are less likely to lead to therapeutic delays or misses with consequences for testosterone breakthroughs.

Most of the economic studies of prostate cancer have focused on cost-effectiveness of screening, ${ }^{46}$ prevention, ${ }^{47}$ cost of illness, ${ }^{48,49}$ hormonal therapy as neoadjuvant and adjuvant to radiotherapy, ${ }^{50,51}$ or comparison of radical treatments. ${ }^{52} \mathrm{~A}$ recently conducted Health Technology Assessment review of studies of orchiectomy versus LHRH agonists also analyzed economic evaluations. Even though the reviewed studies demonstrated lower costs achieved with surgical castration, the authors concluded that orchiectomy could not be recommended when accounting for the extended indications 
Table 3 Summary and disaggregated cost results for three formulations of Eligard ${ }^{\circledR}$ in nine European countries over 12 months

\begin{tabular}{|c|c|c|c|c|c|c|c|c|c|}
\hline & Austria & Belgium & Czech Republic & Hungary & Italy & Lativa & Netherlands & Poland & Portugal \\
\hline \multicolumn{10}{|c|}{ Direct costs* $(95 \% \mathrm{Cl})$} \\
\hline \multirow[t]{2}{*}{ I M } & 4361 & 1982 & 1987 & 1364 & 2796 & $|96|$ & 3665 & 1255 & 3236 \\
\hline & $(3698-5107)$ & $(1887-2078)$ & $(1937-2036)$ & $(135 \mid-1376)$ & (2664-2919) & $(1882-2023)$ & $(342 \mathrm{I}-3905)$ & $(1232-1284)$ & (3073-3407) \\
\hline \multirow[t]{2}{*}{$3 M$} & 2411 & 1084 & 1529 & 1211 & 1949 & 1587 & 2156 & 1072 & 2181 \\
\hline & $(2167-2705)$ & $(|049-||2|)$ & $(|507-| 55 \mid)$ & $(1206-1218)$ & $(1895-2000)$ & $(1558-1616)$ & $(2065-2254)$ & $(1060-1083)$ & $(2112-2255)$ \\
\hline \multirow[t]{2}{*}{$6 M$} & 1784 & 788 & 1446 & 1182 & $|74|$ & 1110 & 1661 & 1014 & 1839 \\
\hline & $(1663-1920)$ & $(77 \mid-805)$ & $(1435-1455)$ & $(1179-1184)$ & $(1716-1765)$ & $(1093-1122)$ & $(1617-1704)$ & $(1010-1020)$ & $(|806-| 87 \mid)$ \\
\hline \multicolumn{10}{|c|}{ Aggregated costs ${ }^{\dagger}(95 \% \mathrm{Cl})$} \\
\hline \multirow[t]{2}{*}{$\mathrm{I} M$} & 4502 & 2136 & 2042 & 1437 & 2929 & 2116 & 3851 & 1305 & 3321 \\
\hline & $(3893-5157)$ & $(2030-2242)$ & $(1992-2093)$ & $(1418-1456)$ & $(2817-3054)$ & $(2038-2174)$ & $(3586-4070)$ & $(1280-1334)$ & $(3179-3533)$ \\
\hline \multirow[t]{2}{*}{$3 M$} & 2462 & 1140 & $|55|$ & 1240 & 2003 & 1649 & 2224 & 1091 & 2214 \\
\hline & $(2259-2711)$ & $(1098-1179)$ & $(1530-1572)$ & $(1233-1249)$ & $(1952-2060)$ & $(1615-1675)$ & $(2128-2306)$ & $(1079-1108)$ & $(2161-2305)$ \\
\hline \multirow[t]{2}{*}{$6 M$} & 1809 & 815 & 1456 & 1196 & 1767 & 1140 & 1694 & 1024 & 1855 \\
\hline & $(1698-1932)$ & $(796-834)$ & $(\mid 447-1466)$ & $(1192-1199)$ & $(1745-1790)$ & $(\mid 125-1152)$ & $(1648-1734)$ & $(1019-1030)$ & $(1824-1896)$ \\
\hline \multicolumn{10}{|c|}{ Cost of Eligard } \\
\hline I M & $1282^{\circ}$ & 1148 & 1585 & 1252 & 1797 & 1454 & 1282 & 981 & 1778 \\
\hline $3 M$ & 1282 & 778 & 1369 & 1167 & 1550 & 1384 & 1282 & 962 & 1598 \\
\hline $6 M$ & 1238 & 640 & 1369 & 1160 & 1550 & 1013 & 1238 & 962 & 1559 \\
\hline \multicolumn{10}{|c|}{ Cost of visits (number of visits) } \\
\hline I M & $3080(12.0)$ & $834(12.0)$ & $1094(12.0)$ & $112(12.0)$ & $998(12.0)$ & $507(12.0)$ & $2384(12.0)$ & $274(12.0)$ & $1457(12.0)$ \\
\hline $3 M$ & $1129(4.4)$ & $306(4.4)$ & $438(4.8)$ & $45(4.8)$ & $399(4.4)$ & $203(4.8)$ & $874(4.4)$ & $110(4.8)$ & $583(4.8)$ \\
\hline $6 M$ & $545(2.1)$ & $148(2.1)$ & $210(2.3)$ & $21(2.3)$ & $191(2.1)$ & $97(2.3)$ & $422(2.1)$ & $53(2.3)$ & $279(2.3)$ \\
\hline \multicolumn{10}{|c|}{ Nonmedical costs $\S$} \\
\hline I M & 68.40 & 52.80 & 46.56 & 65.10 & 48.00 & 135.24 & 84.00 & 25.95 & 50.40 \\
\hline $3 M$ & 25.08 & 19.36 & 18.62 & 26.04 & 19.20 & 54.10 & 30.80 & 10.38 & 20.16 \\
\hline $6 M$ & 12.11 & 9.35 & 8.92 & 12.48 & 9.20 & 25.92 & 14.88 & 4.97 & 9.66 \\
\hline \multicolumn{10}{|c|}{ Indirect $\cos t^{\#}$} \\
\hline $\mathrm{I} M$ & 71.43 & 101.09 & 8.87 & 7.80 & 85.71 & 20.13 & 101.74 & 23.79 & 34.64 \\
\hline $3 M$ & 26.19 & 37.07 & 3.55 & 3.12 & 34.29 & 8.05 & 37.31 & 9.52 & 13.86 \\
\hline $6 M$ & 12.65 & 17.90 & 1.70 & 1.50 & 16.43 & 3.86 & 18.02 & 4.56 & 6.64 \\
\hline
\end{tabular}

Notes: Uncertainty intervals refer to results from the probabilistic sensitivity analysis. *Medical costs borne by the payer; ${ }^{\dagger}$ direct plus indirect and nonmedical costs; ${ }^{\S}$ public transport; "productivity loss based on minimum wage and accounting for retirement status. As adverse event costs were 0 in most cases and did not exceed $€ 0.70$ for any formulation in any country, these have been omitted from the table. Registered trademarks of Eligard ${ }^{\circledR}$, Sanofi S.A./Tolmar Therapeutics Inc (Fort Collins, CO, USA). Abbreviations: $\mathrm{Cl}$, confidence interval; I M, I-monthly; 3 M, 3-monthly; 6 M, 6-monthly.

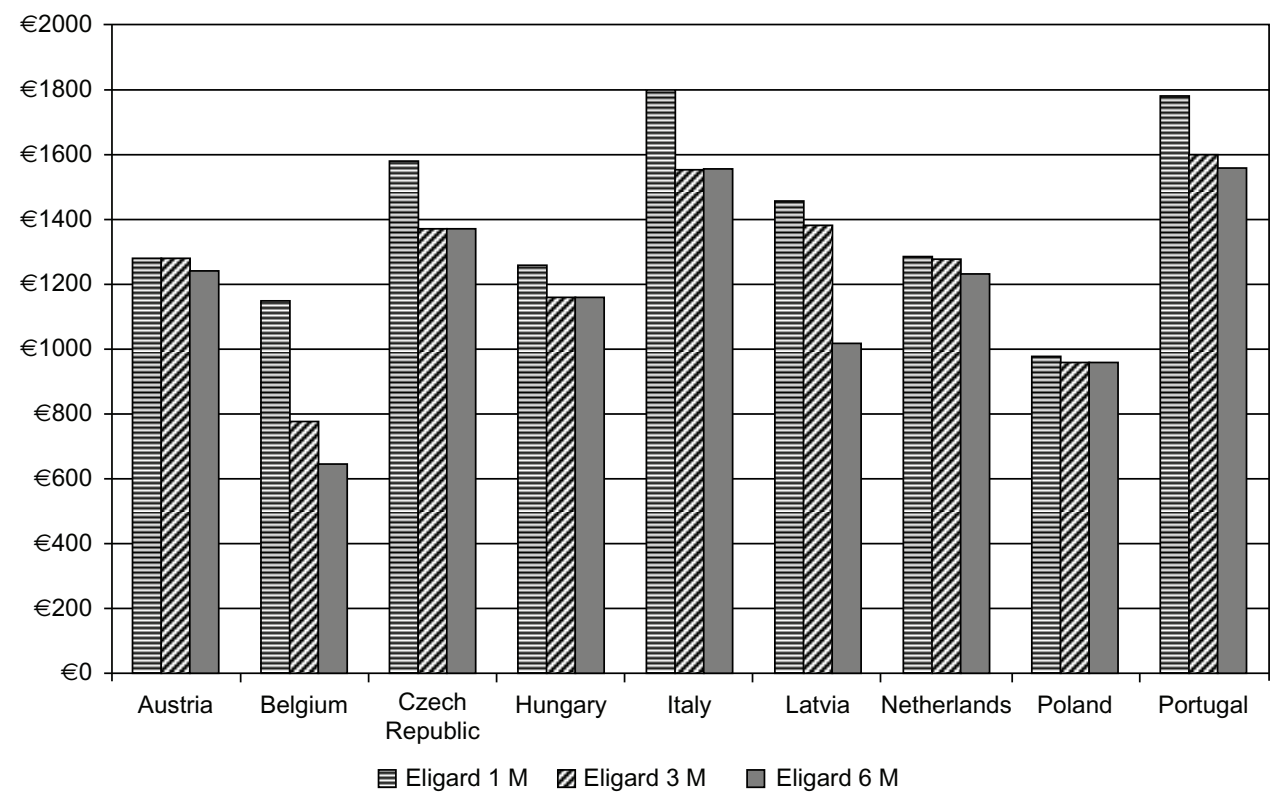

Figure 3 Annual cost of leuprolide acetate in Eligard ${ }^{\circledR}$ I M, 3 M, and 6 M treatments.

Note: Registered trademarks of Eligard ${ }^{\circledR}$, Sanofi S.A./Tolmar Therapeutics Inc (Fort Collins, CO, USA).

Abbreviations: I M, I-monthly; 3 M, 3-monthly; 6 M, 6-monthly. 


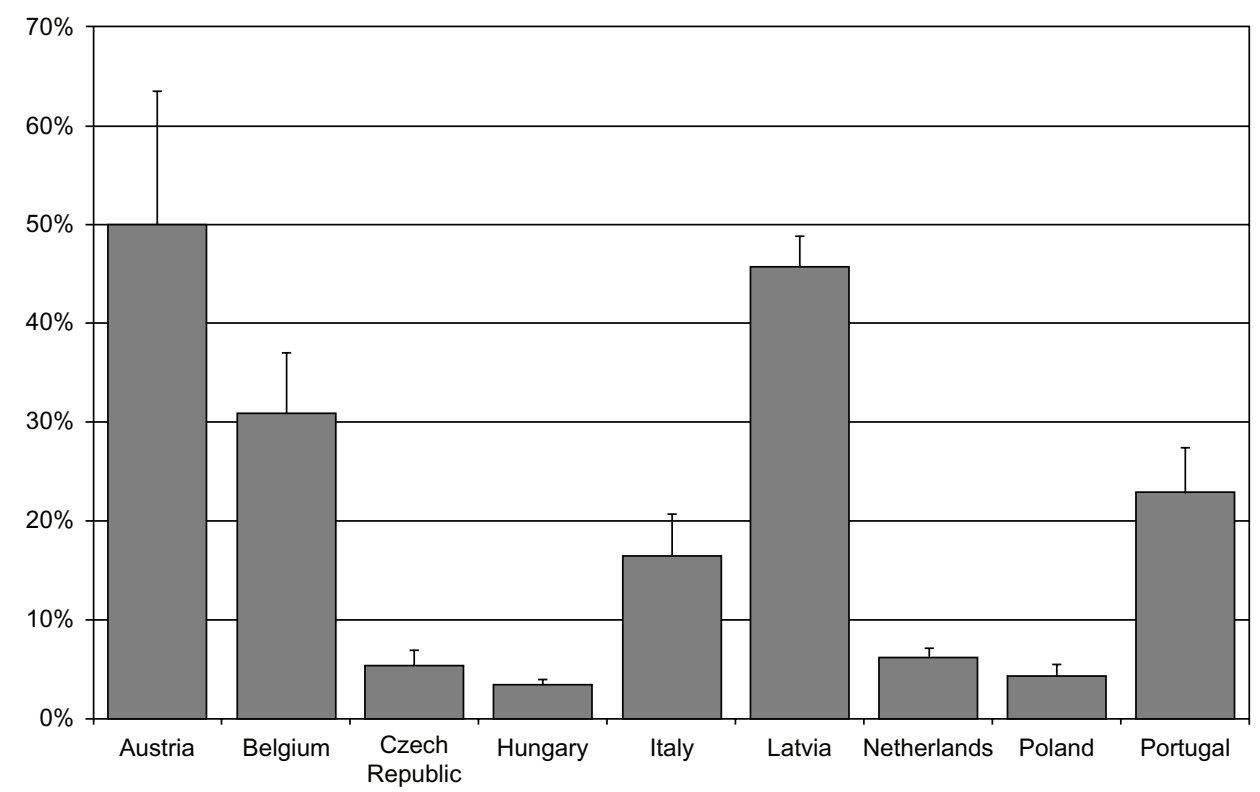

Figure 4 Percentage of additional treatment visits which could be funded with savings achieved from switching all patients from Eligard ${ }^{\otimes} 3 \mathrm{M}^{\text {and }}$ Eligard ${ }^{\otimes}$ I M to Eligard ${ }^{\otimes} 6 \mathrm{M}$ Note: Registered trademarks of Eligard ${ }^{\circledR}$, Sanofi S.A./Tolmar Therapeutics Inc (Fort Collins, CO, USA).

Abbreviations: 3 M, 3-monthly; I M, I-monthly; 6 M, 6-monthly.

for temporary hormone deprivation..$^{53}$ In addition, the cost advantage of orchiectomy versus hormonal treatment may not be evident in all patients when considering the length of hospitalization following surgery and the duration of hormonal treatment being critical in economic evaluation. ${ }^{54}$ In Sweden, orchiectomy and hormonal treatments were found to be equivalent at 8 days of hospitalization and
18 months of hormonal treatment. ${ }^{55}$ Another economic analysis demonstrated that in the United States, orchiectomy was likely the most cost effective, while combined androgen blockade was the least cost effective treatment option, although leuprolide was not among the comparators. ${ }^{56}$ While this study was comprehensive, the economic model was based on a meta-analysis, which did not include newer

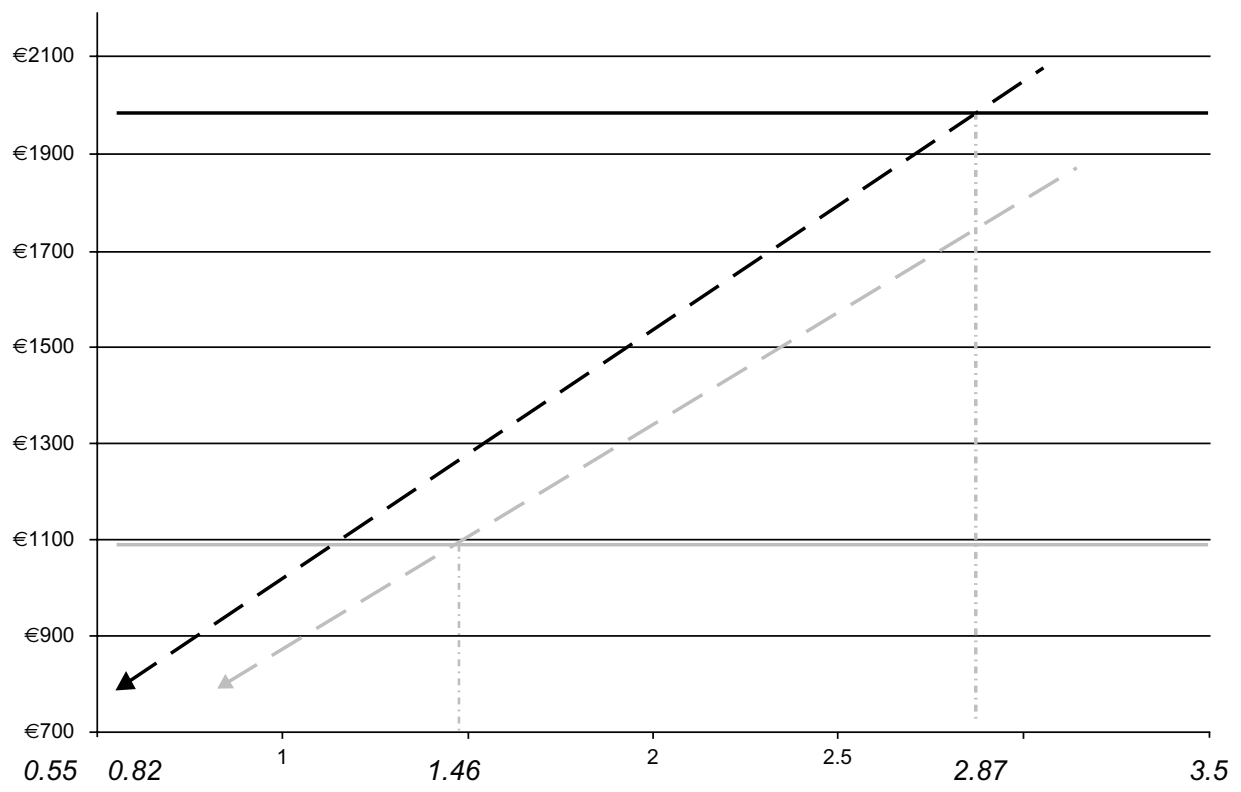

Figure 5 Total annual treatment cost with Eligard ${ }^{\circledR} 6 \mathrm{M}$ as a function of multiples of the monthly cost of Eligard ${ }^{\circledR} \mid \mathrm{M}$ (dashed black line) and $3 \mathrm{M}$ (dashed grey line) in Belgium.

Notes: Solid lines represent total annual treatment costs with I M (black line) and $3 \mathrm{M}$ (grey line). The plot also shows that the annual cost of $6 \mathrm{M}$ treatment (€787.97) is achieved at the baseline monthly cost of Eligard ${ }^{\circledR} 6 \mathrm{M}(€ 320.06)$, which is 0.82 and 0.55 the cost of the $3 \mathrm{M}$ and $6 \mathrm{M}$ formulations, respectively. Registered trademarks of Eligard $^{\circledR}$, Sanofi S.A./Tolmar Therapeutics Inc (Fort Collins, CO, USA).

Abbreviations: I M, I-monthly; 3 M, 3-monthly; 6 M, 6-monthly. 
studies, particularly studies with more advanced depot formulations, ${ }^{12}$ the first $1 \mathrm{M}$ leuprolide depot having been approved by the US Food and Drug Administration in 1999. An economic study conducted in Italy showed, based on observational data, that cyproterone acetate was cost effective when compared to all other hormonal treatment options, although no statistical differences in quality adjusted life years gained were found, and differences between LHRH agonists were not analyzed. ${ }^{57}$

In the treatment of chronic conditions and situations requiring repeated dosing of medications over a period of time, long-acting treatment options are gaining ground. This reflects the increased compliance, decreased discontinuation rates, and patient preference for less frequent administrations; this is especially true when the mode of administration is unpleasant, painful, or causes side effects. In gynecological practice, long-acting reversible contraceptives and LHRH analogues provide adequate treatment options with fewer interventions. Recently, long-acting reversible contraceptive methods in the UK were demonstrated to be cost effective when compared to daily administration of oral contraceptives. ${ }^{58}$ Similarly, long-acting drugs in chronic obstructive pulmonary disease allowed for cost savings due to reduction in exacerbation rate and frequency of hospitalization. By analogy to chronic obstructive pulmonary disease, it is theoretically possible that a less frequent dosing schedule of Eligard ${ }^{\circledR}$ would increase compliance and, as a consequence, reduce the risk of additional hospitalizations, ultimately leading to a decrease in costs.

Control of testosterone is the primary objective of ADT. Is has been reported that the level of testosterone at 6 months since the initiation of ADT is a significant predictor of survival, with better control of testosterone associated with improved survival. ${ }^{59}$ It is therefore plausible that differential testosterone control of different LHRH agonists was responsible for trends observed versus orchiectomy in a meta-analysis. ${ }^{60}$ Following surgical orchiectomy, castration testosterone levels are reached within 4 weeks in all patients. ${ }^{61,62}$ However, clinical trials covering different LHRH agonists have shown that not all patients on LHRH agonists reach the required castration threshold, with testosterone levels above $50 \mathrm{ng} / \mathrm{dL}$ in $5 \%-17 \%$ and above $20 \mathrm{ng} / \mathrm{dL}$ in $13 \%-34 \%$ of patients. ${ }^{41,63-66}$

In addition, once suppression of testosterone production is achieved by LHRH agonists, there should be no breakthrough rises in hormone levels, as defined by a spike above $50 \mathrm{ng} / \mathrm{dL} .{ }^{41,67}$ These breakthroughs could indicate therapy failure and may result in cancer growth, if not controlled.
This has been demonstrated to occur at incidences varying from $2 \%-24 \%$ in patients on LHRH agonists, but not specifically Eligard ${ }^{\circledR}{ }^{66,68-73}$ In addition to breakthroughs, in approximately $10 \%$ of the patients receiving LHRH agonists, repeat injections are associated with transient testosterone increases, resulting in miniflares, ${ }^{69,70}$ which are defined as increases in testosterone levels $\geq 50 \mathrm{ng} / \mathrm{dL}$ within 12 hours after the second or subsequent injection of the LHRH agonist. ${ }^{74}$ Drug delivery plays an important role in the bioavailability of leuprolide. ${ }^{75}$ In a randomized controlled trial with two treatment arms using different formulations of leuprolide and one arm using goserelin, of the 40 patients who received leuprolide $3.75 \mathrm{mg}$ and $7.5 \mathrm{mg}, 26.3 \%$ and $25 \%$, respectively, did not reach castration levels, considering a testosterone cutoff $\leq 50 \mathrm{ng} / \mathrm{dL}$. Furthermore, $68.4 \%$ and $30 \%$, respectively, did not reach castration levels, considering a testosterone cutoff $\leq 20 \mathrm{ng} / \mathrm{dL}$; the difference at this cutoff was statistically significant. ${ }^{76}$

The fact that not all patients achieve castration testosterone levels as a result of hormonal ADT, as well as the occurrence of breakthroughs and miniflares, further emphasizes the need to select effective formulations. A recent systematic review confirmed the superior control of testosterone with Eligard ${ }^{\circledR}$, as the percentage of patients not achieving castration with classical leuprolide formulations was found to be $1.2 \%-5 \%$ at the $50 \mathrm{ng} / \mathrm{mL}$ threshold and $8 \%-13 \%$ at the $20 \mathrm{ng} / \mathrm{mL}$ threshold. ${ }^{77}$ No injection-related testosterone escapes (miniflares) were reported, and the percentage of patients experiencing breakthrough testosterone escapes was $1 \%$ with Eligard ${ }^{\circledR} 3 \mathrm{M}$ and $6 \mathrm{M}$ and $0 \%$ with Eligard $^{\circledR} 1 \mathrm{M}^{78}$ In contrast, $10 \%$ of patients treated with conventional LHRH agonists experienced miniflares and 4\%-12.5\% experienced breakthroughs. The occurrence of miniflares might be related to the frequency of drug administration (ie, $1 \mathrm{M}$ versus $3 \mathrm{M}$ versus $6 \mathrm{M}$ ), while the effectiveness of achieving castration levels can partly be related to persistence (and compliance). Based on a recent prostate cancer registry study of 1521 patients, it has been found that persistence varied with age and with time from treatment initiation; more than one-third of patients was found to have discontinued treatment during the initial 6 months of therapy. The data registry was comprised of data prior to the availability of a $6 \mathrm{M}$ formulation of leuprolide. The authors suggested that improved persistence during the first 6 months of therapy may result in better outcomes. ${ }^{78}$ Dropout rates reported in clinical trials were very low, but registry studies reflecting routine clinical practice could provide further insights into the relative effectiveness of different frequencies of leuprolide administration. 
Furthermore, not only the type of depot formulation or the dosing frequency, but also the dosage of the LHRH agonist used in ADT may have implications for treatment effectiveness and the associated costs. A recent Bayesian meta-analysis of four randomized controlled trials showed relative benefit of leuprolide $7.5 \mathrm{mg}$ over $3.75 \mathrm{mg}$ to be $11 \%$ (relative benefit $=1.11 ; 95 \%$ credible interval: 0.60 to 1.86 ), equal to a mean absolute benefit of $9.1 \%$; the probability of the $7.5 \mathrm{mg}$ dose was more effective than the lower dose, which was $68.1 \% .{ }^{79}$ An economic evaluation incorporated meta-analysis data on testosterone nadir values and modeled improved survival on the $22.5 \mathrm{mg}$ dose of leuprolide compared to $11.25 \mathrm{mg}$ based on $3 \mathrm{M}$ treatments. ${ }^{80}$ The authors used most of the studies we identified in our search, but they did not compare different dosing frequencies, hence they could not capture potential additional savings from using the $6 \mathrm{M}$ formulation. The authors highlighted, however, the importance of the dose of leuprolide with inferior response rates of the $22.5 \mathrm{mg} 6 \mathrm{M}$ formulation. For this reason, this formulation had not been submitted for European registration, ${ }^{81}$ while the $45 \mathrm{mg}$ dose achieved effective testosterone control. ${ }^{42}$

Our results are based on the drug cost of leuprolide gel. With other leuprolide products being more expensive on a monthly basis, ${ }^{80}$ the economic advantage for the $6 \mathrm{M}$ Eligard ${ }^{\circledR}$ would be even more pronounced. On the other hand, with more expensive drugs, the advantage of $3 \mathrm{M}$ over $1 \mathrm{M}$ regimens might be smaller, as drugs, costs would constitute a larger share of the total, thus making the savings from other resources, utilization less apparent. If any of the alternative - existing or future-leuprolide formulations were to be less expensive on a monthly basis, the magnitude of cost savings achievable from switching to Eligard ${ }^{\mathbb{B}} 6 \mathrm{M}$ would indicate the required price reduction for that alternative.

Our economic evaluation is based on the finding of comparable efficacy and safety of the three formulations of Eligard ${ }^{\circledR}$. It must be emphasized that only observational studies were identified, and therefore the evidence base is relatively weak. Findings of this evaluation must also be viewed in light of the 12-month time horizon limited by existing clinical evidence. Further studies, particularly randomized trials and large prospective registry studies, are needed to compare long-term efficacy and safety of different dosages of Eligard ${ }^{\circledR}$ and other formulations of leuprolide.

\section{Conclusion}

In conclusion, Eligard ${ }^{\circledR} 1 \mathrm{M}, 3 \mathrm{M}$, and $6 \mathrm{M}$ formulations offer comparable efficacy when measured by testosterone suppression, comparable safety profiles, and treatment discontinuation rates. Different dosing schedules are associated with different frequencies of specialist consultations, which have considerable economic implications. While patient preference and clinical considerations are most important in choosing the formulation of leuprolide, the $6 \mathrm{M}$ formulation offers the greatest cost savings and should be considered for eligible patients in Europe.

\section{Acknowledgments}

The publication of this review was supported by an unrestricted grant from Astellas Pharma Europe Ltd.

\section{Disclosure}

Jaro Wex is the director of Pharmarchitecture, an independent health outcomes consultancy. Ahmed Abou-Setta worked at Pharmarchitecture during the study. At the time of completion of the study, Manpreet Sidhu, Isaac Odeyemi, and Peny Retsa were employees of Astellas Pharma Ltd, Europe. Bertrand Tombal is a urologist and has not received any financial benefits as a result of participation in this study. The authors report no other conflicts of interest in this work.

\section{References}

1. Ferlay J, Steliarova-Foucher E, Lortet-Tieulent J, et al. Cancer incidence and mortality patterns in Europe: Estimates for 40 countries in 2012. Eur J Cancer. 2013;49(6):1374-1403.

2. Cancer Research UK. Prostate cancer statistics [homepage on the Internet]. London, UK: Cancer Research UK. Available from: http://info.cancerresearchuk.org/cancerstats/types/prostate. Accessed April 3, 2013.

3. Bray F, Ren JS, Masuyer E, Ferlay J. Global estimates of cancer prevalence for 27 sites in the adult population in 2008. Int J Cancer. 2013;132(5):1133-1145.

4. International Agency for Research on Cancer. GLOBOCAN 2008, WHO Europe Region. Available from: http://globocan.iarc.fr/. Accessed April 3, 2013.

5. Ryan CJ, Elkin EP, Small EJ, Duchane J, Carroll P. Reduced incidence of bony metastasis at initial prostate cancer diagnosis: data from CaPSURE. Urol Oncol. 2006;24(5):396-402.

6. Schröder FH, Hugosson J, Carlsson S, et al. Screening for prostate cancer decreases the risk of developing metastatic disease: findings from the European Randomized Study of Screening for Prostate Cancer (ERSPC). Eur Urol. 2012;62(5):745-752.

7. Ward JF, Moul JW. Biochemical recurrence after definitive prostate cancer therapy. Part I: defining and localizing biochemical recurrence of prostate cancer. Curr Opin Urol. 2005;15(3):181-186.

8. Klotz LH. PSA recurrence: definitions, PSA kinetics, and identifying patients at risk. Can J Urol. 2006;13 Suppl 2:43-47.

9. Heidenreich A, Bastian PJ, Bellmunt J, et al. Guidelines on Prostate Cancer. Arnhem, the Netherlands: European Association of Urology; 2012. Available from: http://www.uroweb.org/gls/pdf/08\%20 Prostate\%20Cancer_LR\%20March\%2013th\%202012.pdf. Accessed April 3, 2013.

10. Mcleod DG. Hormonal therapy: historical perspective to future directions. Urology. 2003;61(2 Suppl 1):3-7.

11. Wassersug RJ, Johnson TW. Modern-day eunuchs: motivations for and consequences of contemporary castration. Perspect Biol Med. 2007;50(4):544-556. 
12. Seidenfeld J, Samson DJ, Aronson N, et al. Relative effectiveness and cost-effectiveness of methods of androgen suppression in the treatment of advanced prostate cancer. Evid Rep Technol Assess (Summ). 1999;(4):i-X, 1-246, I1-I36, passim.

13. Fujikawa K, Awakura Y, Okabe T, Watanabe R, Nishimura S. [Cost-utility analysis of androgen ablation therapy in metastatic prostate cancer.] Nippon Hinyokika Gakkai Zasshi. 2003;94(4):503-511. Japanese.

14. Bolla M, Collette L, Blank L, et al. Long-term results with immediate androgen suppression and external irradiation in patients with locally advanced prostate cancer (an EORTC study): a phase III randomised trial. Lancet. 2002;360(9327):103-106.

15. Miyamoto H, Messing EM, Chang C. Androgen deprivation therapy for prostate cancer: current status and future prospects. Prostate. 2004;61(4):332-353.

16. You D, Jeong IG, Kim SW, et al. Impacts of leuprolide acetate on quality of life in patients with prostate cancer: a prospective multicenter study. Scand J Urol Nephrol. 2010;44(6):399-405.

17. Berges R. New trends in managing the prostate cancer patient. European Urology Supplements. 2008;7(13):758-764.

18. Nair B, Wilt T, MacDonald R, Rutks I. Early versus deferred androgen suppression in the treatment of advanced prostatic cancer. Cochrane Database Syst Rev. 2002;(1):CD003506.

19. Mottet N, Bellmunt J, Bolla M, et al. EAU guidelines on prostate cancer. Part II: Treatment of advanced, relapsing, and castration-resistant prostate cancer. Eur Urol. 2011;59(4):572-583.

20. Wilt TJ, MacDonald R, Rutks I, Shamliyan TA, Taylor BC, Kane RL. Systematic review: comparative effectiveness and harms of treatments for clinically localized prostate cancer. Ann Intern Med. 2008;148(6): 435-448.

21. Tanaka N, Fujimoto K, Hirayama A, et al. The primary therapy chosen for patients with localized prostate cancer between the university hospital and its affiliated hospitals in Nara Uro-Oncological research group registration. BMC Urol. 2011;11:6.

22. Utomo NB, Mochtar CA, Umbas R. Primary hormonal treatment in localized and locally advanced prostate cancer: effectiveness and survival predictive factors. Acta Med Indones. 2012;44(1): $10-15$.

23. Toguchi H. Formulation study of leuprorelin acetate to improve clinical performance. Clin Ther. 1992;14 Suppl A:121-130.

24. Chu FM, Jayson M, Dineen MK, Perez R, Harkaway R, Tyler RC. A clinical study of $22.5 \mathrm{mg}$. La-2550: A new subcutaneous depot delivery system for leuprolide acetate for the treatment of prostate cancer. J Urol. 2002;168(3):1199-1203.

25. Perez-Marrero R, Tyler RC. A subcutaneous delivery system for the extended release of leuprolide acetate for the treatment of prostate cancer. Expert Opin Pharmacother. 2004;5(2):447-457.

26. Sharifi R, Soloway M. Clinical study of leuprolide depot formulation in the treatment of advanced prostate cancer. The Leuprolide Study Group. J Urol. 1990;143(1):68-71.

27. Lee M, Browneller R, Wu Z, Jung A, Ratanawong C, Sharifi R. Therapeutic effects of leuprorelin microspheres in prostate cancer. $A d v$ Drug Deliv Rev. 1997;28(1):121-138.

28. Periti P, Mazzei T, Mini E. Clinical pharmacokinetics of depot leuprorelin. Clin Pharmacokinet. 2002;41(7):485-504.

29. Abouelfadel Z, Crawford ED. Leuprorelin depot injection: patient considerations in the management of prostatic cancer. Ther Clin Risk Manag. 2008;4(2):513-526.

30. Ouzaid I, Rouprêt M. [The role of a 6-month depot form of hormone therapy in the treatment of advanced hormone-dependent prostate cancer: Results from the 'ELIRE' observational study.] Prog Urol. 2011;21(12):866-874. French.

31. Crawford ED, Phillips JM. Six-month gonadotropin releasing hormone $(\mathrm{GnRH})$ agonist depots provide efficacy, safety, convenience, and comfort. Cancer Manag Res. 2011;3:201-209.

32. Tunn UW. A 6-month depot formulation of leuprolide acetate is safe and effective in daily clinical practice: a non-interventional prospective study in 1273 patients. BMC Urol. 2011;11:15.
33. Alloul K, Sauriol L, Lafortune L. Meta-analysis and economic evaluation of LHRH agonists' depot formulations in advanced prostatic carcinoma. Can J Urol. 1998;5(3):585-594.

34. Weight CJ, Klein EA, Jones JS. Androgen deprivation falls as orchiectomy rates rise after changes in reimbursement in the US Medicare population. Cancer. 2008;112(10):2195-2201.

35. Odeyemi IAO, Berges R, Bolodeoku J. Economic impact of different preparations of leuprolide acetate in the management of advanced prostate cancer. J Med Econ. 2007;10(2):135-146.

36. Heyns CF, Simonin MP, Grosgurin P, Schall R, Porchet HC; for South African Triptorelin Study Group. Comparative efficacy of triptorelin pamoate and leuprolide acetate in men with advanced prostate cancer. BJU Int. 2003;92(3):226-231.

37. Perez-Marreno R, Chu FM, Gleason D, Loizides E, Wachs B, Tyler RC. A six-month, open-label study assessing a new formulation of leuprolide $7.5 \mathrm{mg}$ for suppression of testosterone in patients with prostate cancer. Clin Ther. 2002;24(11):1902-1914.

38. Marberger M, Kaisary AV, Shore ND, et al. Effectiveness, pharmacokinetics, and safety of a new sustained-release leuprolide acetate $3.75-\mathrm{mg}$ depot formulation for testosterone suppression in patients with prostate cancer: a Phase III, open-label, international multicenter study. Clin Ther. 2010;32(4):744-757.

39. Oefelein MG. Time to normalization of serum testosterone after 3-month luteinizing hormone-releasing hormone agonist administered in the neoadjuvant setting: implications for dosing schedule and neoadjuvant study consideration. J Urol. 1998;160(5):1685-1688.

40. Oefelein MG. Serum testosterone-based luteinizing hormone-releasing hormone agonist redosing schedule for chronic androgen ablation: a phase I assessment. Urology. 1999;54(4):694-699.

41. Oefelein MG, Cornum R. Failure to achieve castrate levels of testosterone during luteinizing hormone releasing hormone agonist therapy: the case for monitoring serum testosterone and a treatment decision algorithm. J Urol. 2000;164(3 Pt 1):726-729.

42. Crawford ED, Sartor O, Chu F, Perez R, Karlin G, Garrett JS. A 12-month clinical study of LA-2585 $(45.0 \mathrm{mg})$ : a new 6-month subcutaneous delivery system for leuprolide acetate for the treatment of prostate cancer. J Urol. 2006;175(2):533-536.

43. Spitz A, Young JM, Larsen L, Mattia-Goldberg C, Donnelly J, Chwalisz K. Efficacy and safety of leuprolide acetate 6-month depot for suppression of testosterone in patients with prostate cancer. Prostate Cancer Prostatic Dis. 2012;15(1):93-99.

44. Fujii Y, Yonese J, Kawakami S, Yamamoto S, Okubo Y, Fukui I. Equivalent and sufficient effects of leuprolide acetate and goserelin acetate to suppress serum testosterone levels in patients with prostate cancer. BJU Int. 2008;101(9):1096-1100.

45. Yri OE, Bjoro T, Fossa SD. Failure to achieve castration levels in patients using leuprolide acetate in locally advanced prostate cancer. Eur Urol. 2006;49(1):54-58; discussion 58.

46. Imamura T, Yasunaga $H$. Economic evaluation of prostate cancer screening with prostate-specific antigen. Int J Urol. 2008;15(4):285-288.

47. Hunt TL, Luce BR, Page MJ, Pokrzywinski R. Willingness to pay for cancer prevention. Pharmacoeconomics. 2009;27(4):299-312.

48. Molinier L, Bauvin E, Combescure C, et al. Methodological considerations in cost of prostate cancer studies: a systematic review. Value Health. 2008;11(5):878-885.

49. Roehrborn CG, Albertsen P, Stokes ME, Black L, Benedict A. Firstyear costs of treating prostate cancer: estimates from SEER-Medicare data. Prostate Cancer Prostatic Dis. 2009;12(4):355-360.

50. Konski A, Sherman E, Krahn M, et al. Economic analysis of a phase III clinical trial evaluating the addition of total androgen suppression to radiation versus radiation alone for locally advanced prostate cancer (Radiation Therapy Oncology Group protocol 86-10). Int J Radiat Oncol Biol Phys. 2005;63(3):788-794.

51. Neymark N, Adriaenssen I, Gorlia T, Caleo S, Bolla M, Brochon D. Costeffectiveness of the addition of early hormonal therapy in locally advanced prostate cancer: results decisively determined by the cut-off time-point chosen for the analysis. Eur J Cancer. 2001;37(14):1768-1774. 
52. Buron C, Le Vu B, Cosset JM, et al. Brachytherapy versus prostatectomy in localized prostate cancer: results of a French multicenter prospective medico-economic study. Int J Radiat Oncol Biol Phys. 2007;67(3): $812-822$.

53. Rohde V, Grabein K, Weidner W, Wasem J, Hessel F. The German HTA report: orchiectomy versus LH-RH analogues in the treatment of advanced prostate carcinoma: are there any consequences for the daily health service? Aktuelle Urol. 2008;39(6):448-455.

54. Turini M, Redaelli A, Gramegna P, Radice D. Quality of life and economic considerations in the management of prostate cancer. Pharmacoeconomics. 2003;21(8):527-541.

55. Rutqvist LE, Wilking N. Analogues of LHRH versus orchidectomy: comparison of economic costs for castration in advanced prostate cancer. Br J Cancer. 1992;65(6):927-929.

56. Bayoumi AM, Brown AD, Garber AM. Cost-effectiveness of androgen suppression therapies in advanced prostate cancer. J Natl Cancer Inst. 2000;92(21):1731-1739

57. Lazzaro C, Bartoletti R, Guazzoni G, et al; for QuABIOS Study Group. Economic evaluation of different hormonal therapies for prostate cancer Final results from the Quality of Life Antiandrogen Blockade Italian Observational Study (QuABIOS). Arch Ital Urol Androl. 2007;79(3): 104-107.

58. Mavranezouli I; for LARC Guideline Development Group. The costeffectiveness of long-acting reversible contraceptive methods in the UK: analysis based on a decision-analytic model developed for a National Institute for Health and Clinical Excellence (NICE) clinical practice guideline. Hum Reprod. 2008;23(6):1338-1345.

59. Perachino M, Monferrato C, Ferraris V. Androgen deprivation therapy (ADT) and testosterone (T) in prostate cancer patients: The lower is really the better. Eur Urol Suppl. 2008;7(3):204.

60. Seidenfeld J, Samson DJ, Hasselblad V, et al. Single-therapy androgen suppression in men with advanced prostate cancer: a systematic review and meta-analysis. Ann Intern Med. 2000;132(7): 566-577.

61. Kaisary AV, Tyrrell CJ, Peeling WB, Griffiths K. Comparison of LHRH analogue (Zoladex) with orchiectomy in patients with metastatic prostatic carcinoma. Br J Urol. 1991;67(5):502-508.

62. Røhl HF, Beuke HP. Effect of orchidectomy on serum concentrations of testosterone and dihydrotestosterone in patients with prostatic cancer. Scand J Urol Nephrol. 1992;26(1):11-14.

63. McLeod D, Zinner N, Tomera K, et al; for Abarelix Study Group. A phase 3, multicenter, open-label, randomized study of abarelix versus leuprolide acetate in men with prostate cancer. Urology. 2001; 58(5):756-761.

64. Kawakami J, Morales A. A comprehensive evaluation in patients with cancer of the prostate on androgen suppression with LHRH agonists [abstract]. J Urol. 2002;176:288.

65. Esquena S, Abascal JM, Trilla E, Morote J. Failure of luteinising hormone releasing hormone agonist therapy to achieve castration. Does it exist [abstract]? European Urology Supplements. 2004; 3(2):57.
66. Tombal B, Berges R. How good do current LHRH agonists control testosterone? Can this be improved with Eligardd ${ }^{\circledR}$ ? European Urology Supplements. 2005;4(8):30-36.

67. Tombal B. Appropriate castration with luteinising hormone releasing hormone (LHRH) agonists: what is the optimal level of testosterone? European Urology Supplements. 2005;4(5):14-19.

68. Khan MS, O'Brien A. An evaluation of pharmacokinetics and pharmacodynamics of leuprorelin acetate 3M-depot in patients with advanced and metastatic carcinoma of the prostate. Urol Int. 1998;60(1): 33-40.

69. Sarosdy MF, Schellhammer PF, Soloway MS, et al. Endocrine effects, efficacy and tolerability of a 10.8-mg depot formulation of goserelin acetate administered every 13 weeks to patients with advanced prostate cancer. BJU Int. 1999;83(7):801-806.

70. Sharifi R, Browneller R; for Leuprolide Study Group. Serum testosterone suppression and potential for agonistic stimulation during chronic treatment with monthly and 3-month depot formulations of leuprolide acetate for advanced prostate cancer. J Urol. 2002;168(3): 1001-1004.

71. Morote J, Esquena S, Abascal JM, et al. Failure to maintain a suppressed level of serum testosterone during long-acting depot luteinizing hormone-releasing hormone agonist therapy in patients with advanced prostate cancer. Urol Int. 2006;77(2):135-138.

72. Morote J, Planas J, Raventos CX, et al. The serum testosterone castration level with clinical relevance [abstract]. European Urology Supplements. 2007;6:29

73. Zlotta A, Debruyne FMJ. Expert opinion on optimal testosterone control in prostate cancer. European Urology Supplements. 2005;4(8):37-41.

74. Tombal B. The importance of testosterone control in prostate cancer. European Urology Supplements. 2007;6(15):834-839.

75. Teutonico D, Montanari S, Ponchel G. Leuprolide acetate: pharmaceutical use and delivery potentials. Expert Opin Drug Deliv. 2012;9(3):343-354.

76. Dias Silva É, Ferreira U, Matheus W, et al. Goserelin versus leuprolide in the chemical castration of patients with prostate cancer. Int Urol Nephrol. 2012;44(4):1039-1044.

77. Novara G, Galfano A, Secco S, Ficarra V, Artibani W. Impact of surgical and medical castration on serum testosterone level in prostate cancer patients. Urol Int. 2009;82(3):249-255.

78. Fuldeore MJ, Brook RA, Smeeding J, Dabbous OH. Leuprolide acetate persistence varies by age in patients with prostate cancer [abstract]. Value Health. 2008;11(3):A73.

79. Payne HA, Edwards SJ. Efficacy of leuprorelin $3.75 \mathrm{mg}$ compared to $7.5 \mathrm{mg}$ in the treatment of prostate cancer: systematic review and meta-analysis [abstract]. Value Health. 2008;11(6):A459.

80. Iannazzo S, Pradelli L, Carsi M, Perachino M. Cost-effectiveness analysis of LHRH agonists in the treatment of metastatic prostate cancer in Italy. Value Health. 2011;14(1):80-89.

81. Sethi R, Sanfilippo N. Six-month depot formulation of leuprorelin acetate in the treatment of prostate cancer. Clin Interv Aging. 2009;4: 259-267.
ClinicoEconomics and Outcomes Research

\section{Publish your work in this journal}

ClinicoEconomics \& Outcomes Research is an international, peerreviewed open-access journal focusing on Health Technology Assessment, Pharmacoeconomics and Outcomes Research in the areas of diagnosis, medical devices, and clinical, surgical and pharmacologica intervention. The economic impact of health policy and health systems

\section{Dovepress}

organization also constitute important areas of coverage. The manuscript management system is completely online and includes a very quick and fair peer-review system, which is all easy to use. Visit http://www.dovepress.com/testimonials.php to read real quotes from published authors. 